\title{
The Relationship between Team Risk Factors and IT Governance under ERP Environment
}

\author{
Wen-Hsien Tsai (Corresponding author) \\ Department of Business Administration, National Central University \\ Jhongli, Taoyuan 32001, Taiwan \\ E-mail: whtsai@mgt.ncu.edu.tw \\ Elliott T.Y. Hwang \\ Department of Information Management, Chung Yuan Christian University \\ Jhongli, Taoyuan 32023, Taiwan \\ E-mail: eliott01@ms3.hinet.net \\ Jui-Chu Chang \\ Department of Business Administration, National Central University \\ Jhongli, Taoyuan 32001, Taiwan \\ E-mail: rcchang@tw.ibm.com \\ Sin-Jin Lin \\ Department of Business Administration, National Central University \\ Jhongli, Taoyuan 32001, Taiwan \\ E-mail: annman1204@gmail.com
}

Received: June 10, 2011

Accepted: July 20, 2011

Published: November 1, 2011

doi:10.5539/ijbm.v6n11p21

URL: http://dx.doi.org/10.5539/ijbm.v6n11p21

\begin{abstract}
The implementation team problem is one of the critical elements lead to ERP project failure. The purpose of this research is to explore the relationship between team risk factors and IT governance. The IT governance includes five important domains, that is, IT strategic alignment, IT value delivery, IT resource management, IT risk management, and IT performance management. Our research results indicate that, among five domains of IT governance, strategic alignment is the most important area. As for the team risk factors, two main team risk factors are "Lack of cross-functional team members" and "IT members' lack of specialized knowledge required by the ERP project". Companies that encountered these team risk factors during ERP project implementation have lower IT governance achievement level than those that did not. It is suggested that Corporations should train their IT members in specialized ERP knowledge and set up a cross-functional team for ERP implementation in order to achieve effective IT governance.
\end{abstract}

Keywords: Enterprise Resource Planning (ERP), IT governance, Team risk

\section{Introduction}

In past two decades, numerous companies have implemented Enterprise Resource Planning (ERP) systems to sustain competitive advantages in a dramatically changing operating environment. The advantages of implementing ERP systems include reducing cycle time, improving flow efficiency, rapidly generating financial information, and assisting in the development of new organizational strategies. However, ERP projects were often been found to be too complex and risky to be implemented in business enterprises (Aloini et al., 2007), where their application in software development resulted in implementation failure (Tsai et al., 2007).

Most of ERP project implementations are usually failed and one of the main reasons is implementation team problem. Team risk refers to issues associated with project team members that increase the uncertainty of a project's outcome (Wallace et al., 2004). Unfortunately, lots of control mechanisms do not match the increasing complexity and variety in ERP systems. Van Grembergen (2004) and Bowen et al. (2007) indicated that IT governance was a useful mechanism that generated the value of the business and mitigates risks associated with IT implementation. Further, ITGI (2003) pointed out that the ultimate responsibility for carrying out IT governance in company lay with the boards of directors. Regardless of the risk assessment had been viewed as a critical category of board of IT governance procedure, quite a few researchers focused on this issue. The purpose of this research is to explore relationship between team risk factors and IT governance in practice in order to provide evidences based on which corporations can try to resolve the team risk problems to achieve the effective 


\section{IT governance.}

The reminder of this paper is structured as follows. Section 2 provides a review of the related literature. Section 3 describes the methodology adopted for this research. Section 4 presents the empirical results. Finally, Section 5 draws the conclusions and offers implications from the research results.

\section{Literature review}

\subsection{Team risk factors}

Team risk refers to issues associated with project team members that increase the uncertainty of a project's outcome (Wallace et al., 2004). It is necessary to form a skilled-balanced project team having internal and external experts, managerial competencies, deep knowledge of the project process, and IT skills (Aloini et al., 2007; Ngai et al., 2008; Bingi et al., 1999; King and Burgess, 2006; Somers and Nelson, 2004). This indicates that teamwork and the composition of the project teams (i.e., the availability of skilled project members, managers and external consultants) will contribute to the success or failure of ERP implementation. Based on a detailed review of previous literature, these relevant team risk factors are summarized as Table 1.

\section{Insert Table 1 -here}

\subsection{IT governance}

Bernroider (2008) stated that the usefulness of IT in corporations had resulted in the view that IT governance should be assessed to promote or enable business objectives and to eliminate risks during IT implementation. Read (2004) indicated that IT governance was so important, because information and technology issues were far more complicated, and significantly impacted the entire business, for example ERP system. Furthermore, the IT governance is a stable process, requiring ongoing review and adjustment and involves several concepts, including risk management and change management (Jennings, 2004; Posthumusa and Solms, 2005). ITGI (2003) stated that IT governance was focusing on two main parts: IT's delivery of value to the business and mitigation of IT risks. To sum up, IT governance is a useful mechanism that mitigates risks associated with ERP project implementation. Thus, this paper will explore the relationship between team risk factors and IT governance in practice in order to provide evidences based on which corporations can try to resolve the team risk problems to achieve the effective IT governance.

IT governance entails a number of activities for the board management, such as becoming informed of the role and impact of IT on the enterprise, assigning responsibilities, defining constraints within which to operate, measuring performance, managing risk and obtaining assurance (ITGI, 2003). Further, ITGI (2003) pointed out that the ultimate responsibility for carrying out IT governance in company lay with the boards of directors.

IT governance includes five domains which are IT strategic alignment, IT value delivery, IT resource management, IT risk management, and IT performance management (ITGI, 2003). Based on a detailed review of previous literature, many studies stated some policy for the directors to improve IT governance. First, focusing on strategic alignment area, the directors must assure that ERP strategy is aligned with business strategy, technology investment decisions are aligned with business goals, and the ERP organizational structure complements the business model and direction (ITGI, 2003; ITGI, 2004; Hoffman, 2004; Huff et al., 2005; ITGI, 2006a, 2006b). Second, concerning on value delivery area, they must confirm the completeness, quality, and reliability of ERP systems, and ensure ERP investments represent a balance of risk and benefit and that budgets are acceptable (ITGI, 2003; Hoffman, 2004; Huff et al., 2005; Damianides, 2004; ITGI, 2006a, 2006b; Nolan and McFarlan, 2005). Third, dealing with risk management area, they must monitor the effectiveness of internal controls and ensure ERP risks are mitigated, transferred, accepted by effectively risk management (ITGI, 2003; ITGI, 2004; Hoffman, 2004; Nolan and McFarlan, 2005; Damianides, 2004; ITGI, 2006a, 2006b). Fourth, coping with IT resource management area, they must understand the overall architecture of the company's ERP applications portfolio as well as its asset management strategy, and monitor how management determines what ERP resources are needed to achieve strategic goals (ITGI, 2003; ITGI, 2004; Nolan and McFarlan, 2005; ITGI, 2006a, 2006b). Finally, focusing on performance management area, they must oversee the development of key ERP performance metrics and monitor, and evaluate senior management's performance on ERP strategies in operation (ITGI, 2003; Huff et al., 2005; Nolan and McFarlan, 2005; ITGI, 2006a, 2006b). Thus, this research will focus on these five domains to provide effective measures of IT governance for the boards of directors.

\section{Methodology}

\subsection{Research framework}

First, we identified 8 ERP team risk factors and 22 IT governance criteria by reviewing the ERP and IS literatures. Second, we measured the team risk factors and IT governance by using yes/no questions and a two-stage approach, respectively. Then, our sample of 275 organizations in Taiwan with prior experience of implementing ERP systems was used to explore IT governance in order to eliminate risks associated with ERP implementation. Corporations which currently are planning or implementing ERP systems will benefit from the findings of this research. This research not only suggests the main directions for managers to mitigate or eliminate significant team risk factors, but also provides a better understanding of IT governance during ERP implementation for boards of directors.

\subsection{Data collection}

This research applied a two-step approach that consisted of designing the questionnaires and collecting the data. 
The steps are described in detail as follows:

Step1: Listing the ERP team risk factors and IT governance criteria by conducting a literature review, and then evaluating them with a small sample survey. We adopted an iterative process of personal interviews with experts to modify the questionnaire before distributing it. Their comments and suggestions helped us enhance the quality of the questionnaire, and make the survey more concise and easier to understand.

Step 2: Redesigning the survey questionnaire concerning ERP team risk factors and IT governance measures, collecting the data by a large sample, and analyzing the collected data. Data for this research were collected using a questionnaire survey in Taiwan. Manufacturing and service firms were targeted because they relied heavily on the use of ERP. Top 5,000 Largest Corporations in these sectors were included. All of the corporations were registered at the Ministry of Economic Affairs. The criteria for selecting the target companies are the annual revenue is over NT\$ 300 million for manufacturers and NT\$200 million for the service industries.

This research sent out 4,336 questionnaires and received 603 completed questionnaires, indicating an effective response rate of $13.91 \%$. ERP project managers, senior project team members and boards of directors were selected as the respondents because they were the personnel most likely to understand the issues. Of these responses, only organizations with prior experience in implementing ERP systems were selected as our investigative sample. Therefore, after discarding the missing responses and unusable ones, the final investigative samples totaled 275 out of 603 received questionnaires. It is worth mentioned that our data collection effort reflects the typically lower responses that are commonly seen for IS studies in the field, for example, $17 \%$ for Bernroider and Koch's (2001) research and 3.9\% for Rao's (2000) research. Two of the most possible reasons to interpret the low response rate were time constraint and the sizes of the instrument.

\subsection{Variables measurement}

In the questionnaire, Yes/No questions were used to identify which ERP team risk factors actually occurred during the companies' ERP implementation in the investigated companies. In this research, companies in which risk factors had occurred during ERP implementation are assigned the variable 1, and companies in which risk factors had not occurred during ERP implementation are assigned the variable 0. For example, companies in which "Lack of cross-functional team members" occurred during ERP implementation are assigned the value 1 (variable=1), and companies in which "Lack of cross-functional team members" did not occur during ERP implementation are assigned the value 0 (variable $=0$ ).

There are 22 criteria used to measure the achievement level of IT governance. The respondents were asked to evaluate these criteria in terms of their degree of importance and success level by using a 7-point Likert scale ranging from 1 (extremely unimportant) to 7 (extremely important) and from 1 (substantial deterioration) to 7 (substantial success), respectively. This research measured the weighted IT governance success levels for each of five dimensions of IT governance and the composite weighted success levels by using a two-stage approach as follows:

Stage 1: First, in order to obtain the average importance level scores, this research calculated the weights of all the measures by using the importance level scores ( 1 to 7 ) for the $N$ respondent companies.

Stage 2: Having obtained the average importance level scores from Stage 1, we calculated the weighted IT governance success level for each of the five dimensions for the $N$ respondent companies by using the success level scores (1 to 7), and multiplied by average importance level scores. Then, the composite weighted success levels for the $N$ respondent companies were calculated by using the data achieved above for five dimensions of IT governance.

\section{Data analysis and results}

\subsection{Sample demographics}

Of the 275 responses that were implementing or had implemented ERP systems, 208 companies (75.64\%) have fewer than 500 employees, 229 companies $(83.27 \%$ ) have annual revenues below NT\$ 5 billion, and 251 companies (91.27\%) have capital amounts of less than NT\$ 5,000 million. Among these companies, approximately $199(72.36 \%)$ are manufacturers and 76 are members $(27.64 \%)$ of service industries.

\subsection{The status of IT governance practice}

To determine the achievement level of IT governance, the respondents were asked to assess the importance of each measure of the five domains of IT governance by using 7 point Likert scale from "Not Important at all" to "Very Important". The average importance rating and implementation outcome for each domain has been summarized in Table 2. The results indicate that most of the domains of IT governance are considered important, because the average values of importance ratings are all greater than 5 . On the other hand, for the implementation outcome, we can see that respondents indicated that their IT governance structures were useful in their company (the values of implementation outcome are smaller than the average importance scores). According to these results, the boards of directors would focus on the five domains to improve the IT governance in practice, especially in strategic alignment area (the average values of importance ratings are 5.5; it is the top one importance). Consistent with Bernroider (2008), the IT strategic alignment is a major element of IT governance and well-established IT governance will facilitate the success of ERP implementation. The policy implication is that the boards of directors in Taiwanese corporations should enhance the IT governance by focusing on strategic alignment area first and then other domains of IT governance. 


\section{Insert Table 2 - here}

\subsection{The relationship between team risk factors and IT governance}

The main purpose of this research is to explore the relationship between team risk factors and IT governance. The ANOVA analysis results are shown in Table 3. The results reveal that companies that do not encounter these team risk factors during ERP project implementation have better IT governance achievement level. This research also finds that the most critical team risk factor is "Lack of cross-functional team members". There are two reasons why this team risk factor is the most critical. First, this critical risk factor is significantly related to each of five domains of IT governance. Second, among the 275 companies in the sample, companies that encounter this critical team risk factor have the lowest IT governance score compared to other team risk factors. As for the team risk factor "IT members' lack of specialized knowledge required by the ERP project", this team risk factor is also significantly related to "Strategic Alignment", "Value Delivery", "Risk Management", and "Performance Management", and the composite score of IT governance. That is, companies that encountered these team risk factors during ERP project implementation had lower IT governance achievement level than those that did not. Besides, other important team risk factors will be "Inexperienced consultants" and "Vendor's lack of specialized skills".

The research findings have an important potential implication for the boards of directors and managers in making future policies. Corporations should try to resolved two main team risk factors: "Lack of cross-functional team members" and "IT members' lack of specialized knowledge required by the ERP project" in order to achieve the effective IT governance. That is, corporations should train their IT members in specialized ERP knowledge and set up a cross-functional team for ERP implementation in order to achieve effective IT governance.

\section{Conclusions}

\section{Insert Table 3 -here}

To sustain the advantage in a dramatically turbulent environment, companies in the world had implemented enterprise resource planning (ERP) systems which were integrated software solutions applied to manage any organization's resources. The implementation team problem is one of the essential reasons which lead to numerous ERP project implementation failures. IT governance is a useful mechanism that mitigates risks associated with ERP implementation. The purpose of this research is to explore the relationship between team risk factors and IT governance. The information about the research findings yields evidences based on which corporations can try to resolve the team risk problems to achieve the effective IT governance.

Our research results indicate that, among five domains of IT governance, strategic alignment is the most important area. As for the team risk factors, two main team risk factors are "Lack of cross-functional team members" and "IT members' lack of specialized knowledge required by the ERP project". Companies that encountered these two team risk factors during ERP project implementation had lower IT governance achievement level than those that did not. It is suggested that corporations should train their IT members in specialized ERP knowledge and set up a cross-functional team for ERP implementation in order to achieve the effective IT governance.

Nevertheless, some limitations still exist in this research. The low response rate will decrease the generalization of the research results. In addition, the respondents in this research are assumed that they possess the specialized knowledge of ERP and IT governance in their institutions that can help them correctly complete the questionnaires.

\section{Acknowledgement}

The authors would like to thank the National Science Council of Taiwan for financially supporting this research under Contract No: NSC98-2410-H-008-026-MY2.

\section{References}

Aloini, D., Dulmin, R., \& Mininno, V. (2007). Risk Management in ERP Project Introduction: Review of the Literature. Information \& Management, 44 (6), 547-567. http://dx.doi.org/10.1016/j.im.2007.05.004

Bernroider, E., \& Koch, S. (2001). ERP Selection Process in Midsize and Large Organizations. Business Process Management Journal, 7 (3), 251-257. http://dx.doi.org/10.1108/14637150110392746

Bernroider, E. W. N. (2008). IT Governance for Enterprise Resource Planning Supported by the DeLone-McLean Model of Information Systems Success. Information \& Management, 45 (5), 257-269. http://dx.doi.org/10.1016/j.im.2007.11.004

Bingi, P., Sharma, M., \& Godla, J. (1999). Critical Issues Affecting an ERP Implementation. Information Systems Management, 16 (3), 7-14. http://dx.doi.org/10.1201/1078/43197.16.3.19990601/31310.2

Bowen, P. L., Cheung, M. Y. D., \& Rohde, F. H. (2007). Enhancing IT Governance Practices: A Model and Case Study of an Organization's Efforts. International Journal of Accounting Information Systems, 8 (3), 191-221. http://dx.doi.org/10.1016/j.accinf.2007.07.002

Chen, T., Zhang, J., \& Lai, K. K. (2009). An Integrated Real Options Evaluating Model for Information Technology Projects under Multiple Risks. International Journal of Project Management, 27 (8), 776-786. http://dx.doi.org/10.1016/j.ijproman.2009.01.001 
Damianides, M. (2004). Sarbanes-Oxley and IT Governance: New Guidance on IT Control and Compliance. EDPACS: The EDP Audit, Control, and Security Newsletter, 31 (10), 1-14, http://dx.doi.org/10.1201/1079/44191.31.10.20040401/80839.1

Hoffman, T. (2004). IT Oversight Gets Attention at Board Level. Computerworld, (38) 20, 1-3.

Huang, S. M., Chang, I. C., Li, S. H., \& Lin, M. T. (2004). Assessing Risk in ERP Projects: Identify and Prioritize the Factors. Industrial Management and Data System, 104 (8), 681-688, http://dx.doi.org/10.1108/02635570410561672

Huff, S. L. Maher, P. M., \& Munro, M. C. (2005). Adding Value: The Case for Adding IT-Savvy Directors to the Board. Ivey Business Journal, 2, 1-5.

Information Technology Governance Institute (ITGI). (2003). Board briefing on IT governance.

Information Technology Governance Institute (ITGI). (2004). COBIT and IT governance a case research: Allstate.

Information Technology Governance Institute (ITGI). (2006a). Enterprise value: governance of IT investments. The ING case research.

Information Technology Governance Institute (ITGI). (2006b). IT governance executive summary.

Jennings, T. (2004). Change management: an essential tool for IT governance. White Paper, Butler Direct Limited, 1-18.

King, S., \& Burgess, T. (2006). Beyond Critical Success Factors: A Dynamic Model of Enterprise System Innovation. International Journal of Information Management, 26 (1), 59-69, http://dx.doi.org/10.1016/j.ijinfomgt.2005.10.005

Ngai, E. W. T., Law, C. C. H., \& Wat, F. K. T. (2008). Examining the Critical Success Factors in the Adoption of Enterprise Resource Planning. Computers in Industry, 59 (6), 548-564, http://dx.doi.org/10.1016/j.compind.2007.12.001

Nolan, R., \& McFarlan, F. W. (2005). Information Technology and the Board of Directors. Harvard Business Review, 83, 96-106.

Posthumusa, S., \& Solms, R. (2005). IT Oversight: An Important Function of Corporate Governance. Computer Fraud \& Security, 6, 11-17. http://dx.doi.org/10.1016/S1361-3723(05)70222-0.

Rao, S. S. (2000). Enterprise Resource Planning: Business Needs and Technologies. Industrial Management \& Data Systems, 100 (2), 81-88. http://dx.doi.org/10.1108/02635570010286078.

Read, T. J. (2004). Discussion of Director Responsibility for IT Governance. International Journal of Accounting Information Systems, 5 (2), 105-107. http://dx.doi.org/10.1016/j.accinf.2004.01.001.

Somers, T., \& Nelson, K. (2004). A Taxonomy of Players and Activities across the ERP Project Life Cycle. Information \& Management, 41 (3), 257-278. http://dx.doi.org/10.1016/S0378-7206(03)00023-5

Sumner, M. (2000). Risk Factors in Enterprise-Wide/ERP Projects. Journal of Information Technology, 15 (4), 317-327. http://dx.doi.org/10.1080/02683960010009079

Tsai, W. H., Fan, Y. W., Leu, J. D., Chou, L. W., \& Yang, C. C. (2007). The Relationships between Implementation Variables and Performance Improvement of ERP Systems. International Journal of Technology Management, 38 (4), 350-373. http://dx.doi.org/10.1504/IJTM.2007.013406

Van Grembergen, W. (2004). Strategies for information technology governance. Hershey, PA: Idea Group Publishing.

Wallace, L., Keil, M., \& Rai, A. (2004). Understanding Software Project Risk: A Cluster Analysis. Information \& Management, 42 (1), 115-125. http://dx.doi.org/10.1016/j.im.2003.12.007

Table 1. Team risk factors of ERP

\begin{tabular}{|c|c|}
\hline ERP risk factors & Sources \\
\hline $\begin{array}{l}\text { Consultants' lack of understanding of corporate operational } \\
\text { processes }\end{array}$ & \multirow{8}{*}{$\begin{array}{l}\text { Huang et al. (2004), Aloini et al. } \\
\text { (2007), Sumner (2000), Wallace } \\
\text { et al. (2004), Chen et al. (2009) }\end{array}$} \\
\hline Lack of cross-functional team members & \\
\hline Inexperienced consultants & \\
\hline $\begin{array}{l}\text { IT members' lack of specialized knowledge required by the ERP } \\
\text { project }\end{array}$ & \\
\hline Vendors' lack of specialized skills & \\
\hline Frequent team member turnover & \\
\hline Lack of team member support & \\
\hline Inadequately trained development team members & \\
\hline
\end{tabular}


Table 2. Results of IT governance in practice

\begin{tabular}{|l|c|c|}
\hline \multicolumn{1}{|c|}{ IT Governance domains } & Average Importance Rating & Implementation outcome \\
\hline Strategic alignment area & 5.4734 & 4.9291 \\
\hline Value delivery area & 5.3552 & 4.9129 \\
\hline Risk management area & 5.3573 & 4.8624 \\
\hline IT resource management area & 5.3353 & 4.9523 \\
\hline Performance management area & 5.2408 & 4.7099 \\
\hline
\end{tabular}

Table 3. Results for the relationship between team risk factors and IT governance

\begin{tabular}{|c|c|c|c|c|c|c|c|}
\hline Team risk factors (frequency) & $\begin{array}{c}\text { Encountered } \\
\text { or not }\end{array}$ & $\begin{array}{c}\text { Strategic } \\
\text { Alignment }\end{array}$ & $\begin{array}{c}\text { Value } \\
\text { Delivery }\end{array}$ & $\begin{array}{c}\text { Risk } \\
\text { Management }\end{array}$ & $\begin{array}{l}\text { IT Resource } \\
\text { Management }\end{array}$ & $\begin{array}{l}\text { Performance } \\
\text { Management }\end{array}$ & Composite \\
\hline \multirow{3}{*}{$\begin{array}{l}\text { IT members' lack of } \\
\text { specialized knowledge } \\
\text { required by the ERP project } \\
\text { (35) }\end{array}$} & Yes & 4.67143 & 4.63333 & 4.50000 & 4.73620 & 4.39048 & 4.60705 \\
\hline & No & 4.96654 & 4.95370 & 4.91521 & 4.98395 & 4.75651 & 4.92963 \\
\hline & Sig. & 0.075* & $0.025 * *$ & $0.009 * * *$ & 0.107 & $0.033 * *$ & 0.020 ** \\
\hline \multirow{3}{*}{$\begin{array}{l}\text { Lack of cross-functional team } \\
\text { members (45) }\end{array}$} & Yes & 4.51509 & 4.42769 & 4.39694 & 4.55894 & 4.28985 & 4.44966 \\
\hline & No & 5.00996 & 5.00786 & 4.95343 & 5.02940 & 4.79211 & 4.97445 \\
\hline & Sig. & $0.001 * * *$ & $0.000 * * *$ & $0.000 * * *$ & $0.001 * * *$ & $0.001 * * *$ & $0.000 * * *$ \\
\hline \multirow{3}{*}{$\begin{array}{l}\text { Consultants' lack of } \\
\text { understanding of corporate } \\
\text { operational processes }(65)\end{array}$} & Yes & 4.77198 & 4.78358 & 4.70080 & 4.89722 & 4.62631 & 4.77112 \\
\hline & No & 4.97757 & 4.95296 & 4.91237 & 4.96950 & 4.73581 & 4.92493 \\
\hline & Sig. & 0.114 & 0.131 & $0.092 *$ & 0.549 & 0.419 & 0.157 \\
\hline \multirow{3}{*}{$\begin{array}{l}\text { Inexperienced consultants } \\
\text { (43) }\end{array}$} & Yes & 4.65116 & 4.69388 & 4.68464 & 4.81395 & 4.46512 & 4.68093 \\
\hline & No & 4.98047 & 4.95352 & 4.89530 & 4.97808 & 4.75530 & 4.92706 \\
\hline & Sig. & $0.030 * *$ & $0.048^{* *}$ & 0.152 & 0.245 & 0.066* & $0.053^{*}$ \\
\hline \multirow{3}{*}{$\begin{array}{l}\text { Vendors' lack of specialized } \\
\text { skills (24) }\end{array}$} & Yes & 4.54167 & 4.63238 & 4.61207 & 4.73333 & 4.58333 & 4.62814 \\
\hline & No & 4.96601 & 4.93975 & 4.88630 & 4.97337 & 4.72203 & 4.91347 \\
\hline & Sig. & 0.030 ** & 0.069* & 0.147 & 0.186 & 0.496 & $0.081 *$ \\
\hline \multirow{3}{*}{$\begin{array}{l}\text { Inadequately trained } \\
\text { development team members } \\
\text { (13) }\end{array}$} & Yes & 4.71154 & 4.60183 & 4.44231 & 4.72308 & 4.61538 & 4.62246 \\
\hline & No & 4.93977 & 4.92836 & 4.88321 & 4.96380 & 4.71461 & 4.90178 \\
\hline & Sig. & 0.381 & 0.146 & 0.080* & 0.319 & 0.714 & 0.200 \\
\hline \multirow{3}{*}{$\begin{array}{l}\text { Frequent team member } \\
\text { turnover }(18)\end{array}$} & Yes & 4.84722 & 4.80556 & 4.79167 & 4.91111 & 4.55556 & 4.80131 \\
\hline & No & 4.93470 & 4.92044 & 4.86732 & 4.95531 & 4.72074 & 4.89468 \\
\hline & Sig. & 0.696 & 0.552 & 0.727 & 0.831 & 0.478 & 0.618 \\
\hline \multirow{3}{*}{$\begin{array}{l}\text { Lack of team member support } \\
\text { (15) }\end{array}$} & Yes & 4.76667 & 4.73333 & 4.41667 & 4.58446 & 4.33333 & 4.59489 \\
\hline & No & 4.93834 & 4.92328 & 4.88808 & 4.97365 & 4.73165 & 4.90551 \\
\hline & Sig. & 0.481 & 0.366 & $0.045^{* * *}$ & $0.084 *$ & 0.115 & 0.127 \\
\hline
\end{tabular}

notes: ${ }^{*}$ p-value $<0.1 ; * *$ p-value $<0.05 ; * * *$ p-value $<0.01$ 